\title{
Determination of mushroom consumption preferences by using fuzzy analytic hierarchy process
}

\author{
Ayşenur Gürgen ${ }^{1 *}$, Sibel Yildiz ${ }^{1}$, Ümit Cafer Yildiz $^{1}$ \\ ${ }^{1}$ Karadeniz Technical University, Faculty of Forestry, Department of Forest Industry Engineering, Trabzon, \\ Turkey
}

Corresponding author: aysenur.yilmaz@ktu.edu.tr

\begin{abstract}
Mushrooms are delicious, nutritious and consumed foods known as dietary and protein sources. Along with the rapid growth of the world population, the increasing tendency of people to alternate medicine has increased the consumption of mushrooms of which useful/medical features are revealed by scientific studies. As in every consumption behavior, consumption of mushrooms is also a result of preferences. The purpose of this study is to determine mushroom consumption preferences using the fuzzy analytical hierarchy process (AHP). First of all, it was created the analytic hierarchy process, which has the choice of mushrooms and (if any) sub-criteria. The generated AHP was converted into comparative matrices and replied to the experts. Received answers are transformed into fuzzy numbers and the importance levels of preferences are ranked according to their calculated weights.
\end{abstract}

Keywords: Fuzzy analytical hierarchy process, mushroom, consumption preference

\section{Özet}

Mantarlar, lezzetli, diyetetik ve protein kaynağı olarak bilinen ve tüketilen besinlerdir. Dünya nüfusunun hızla çoğalmasının yanında, insanların alternatif tıpa eğilimlerinin de artmasıyla birlikte tıbbi/faydalı özelliklerinin bilimsel çalışmalarla ortaya konan mantarların tüketim miktarları daha da artmıştır. Her tüketim davranışında olduğu gibi mantar tüketimi de birtakım tercihler sonucu oluşur. Bu çalışmanın amacı bulanık analitik hiyerarşi prosesi kullanarak mantar tüketim tercihlerinin belirlenmesidir. Öncelikle mantar seçimi tercihlerinin ve alt kriterlerinin olduğu analitik hiyerarşi prosesi oluşturmuştur. Oluşturulan AHP karşılaştırmalı matrisler haline getirilmiş ve uzman kişiler tarafindan cevaplandırılmıştır. Alınan cevaplar bulanık sayılara dönüştürülerek tercihlerin önem düzeyleri, hesaplanan ağırlıklarına göre sıralanmıştır.

Anahtar kelimeler: Bulanık analitik hiyerarşi prosesi, mantar, tüketim tercihi

\section{Introduction}

The world population is growing rapidly, and people's feeding behavior is changing with the increased speed of population. People have tended to focus more natural products in order to be able to lead a healthy life. Mushroom is also one of the natural products. Because mushrooms have many medicinal properties such as antioxidant (Sevindik et al. 2018) antimicrobial (Baraza et al. 2016), anticancer (Patel and Goyal 2012) proven by scientific studies. In addition, 90-95\% of the mushrooms are water (Manzi et al.2001) and so are a dietary nutrient. Also, mushrooms have low fat (Kavishree et al. 2008) and high protein (Danell and Eaker 1992), thus, making this group of foods more attractive. Especially in this sense, mushrooms can be suggested to close the protein lack of vegetarian people. 
Many species of mushrooms are cultivated and produced throughout the world. The most commonly produced mushroom species in our country is Agaricus bisporus, known as the white parasol mushroom. This sorting is followed by Pleurotus ostreatus named beech mushroom on the market (Eren and Pekşen 2014). Although mushroom production in Turkey is not long before, it has a tendency to increase the production day by day. The mushroom production, which was 15,000 tons in 2004, reached 21,559 tons in 2010 , and in 2017 it increased by $219 \%$ to 40,874 tons compared to 2004 (TUIK 2018).

There are some reasons why mushrooms are preferred, bought and consumed, as with other purchased product group. Many products are produced in order to satisfy unlimited consumers' desires and needs. These individual activities constitute consumption behaviors of people (Kizllaslan and Kizılaslan 2008; Zikmund and d'Amico 1998). Consumption is actually Multi-Criteria Decision Making (MCDM) behavior because it occurs by evaluating more than one criterion. MCDM is the final choice by resulting in the evaluation of the consequent limitations such as classification, sorting, elimination, etc. (Yoon and Hwang1995). There are many MCDM techniques in the literature that are also used in real life. One of them is the Analytical Hierarchy Process (AHP) developed by Satty in 1977 (Saaty 1977). This method is a mathematical method that evaluates both quantitative and qualitative priorities, taking into account the priorities that groups or individuals use when making decisions. However, using of crisp value to evaluate qualitative factors is a disadvantage of this method. In order to avoid this disadvantage, the use of fuzzy numbers instead of crisp numbers has been proposed (Karsak and Tolga 2001). Fuzzy numbers are a component of the concept of fuzzy logic. They were first proposed by Zadeh in 1965 (Zadeh 1965). In this theory, unclear expressions such as 'low', 'middle', 'high' are used instead of certain expressions such as 'yes' or 'no'. This allows the consumers to express themselves better, to reflect their feelings fully.

Some scientific researches have been carried out to determine the consumption of mushrooms and consumption habits in Turkey. Özkan et al. (2000) investigated the consumption of mushrooms and consumption behavior in Ankara and Antalya provinces. Like mentioned above, there are also researches of Kahramanmaraş and Trabzon province investigated by Paksoy and Aksüt (2012) and Y1lmaz et al(2016)respectively. Knowing what consumers are paying attention to when purchasing goods or services is crucial to the continuity and profitability of the business for those who market or service the consumer behavior analysis service (Kizılaslan and Kizılaslan, 2008). The importance given to consumer behavior will provide both producers and consumers satisfaction. In this study, mushroom consumption preferences were determined using by the fuzzy analytical hierarchy process because of its superiority to classical AHP.

\section{Material and Methods}

In this study, the fuzzy AHP method developed by Buckley (1985) was implemented. This method has some steps to be used. Firstly, the experts evaluate each criterion and express linguistically the importance of each criterion. The fuzzy decision matrix is obtained in the data collected from the experts as below;

$\tilde{C}^{k}=\left[c_{i j}\right]_{n x n}=\left[\begin{array}{ccccc}1 & \tilde{c}_{12} & \tilde{c}_{13} & \ldots & \tilde{c}_{1 n} \\ \tilde{c}_{21} & 1 & \tilde{c}_{23} & \ldots & \tilde{c}_{2 n} \\ \cdot & \cdot & \cdot & \ldots & \cdot \\ \cdot & \cdot & . & \ldots & . \\ \tilde{c}_{n 1} & \tilde{c}_{n 2} & \tilde{c}_{n 3} & \ldots & 1\end{array}\right]$

$k=1,2, \ldots ., \mathrm{p}$

$i, j=1,2, \ldots ., \mathrm{n}$ 
where, $\tilde{C}^{k}$ is fuzzy decision matrix that represents the importance degrees of criteria given $\mathrm{k}^{\text {th }}$ expert, $\mathrm{p}$ is the number of experts, $\mathrm{n}$ is the number of criteria. $c_{i j}$ indicates the fuzzy comparison value of criterion $i$ to creation $j$.

In the second stage, the linguistic answers given by experts for pairwise comparisons are transformed into triangular fuzzy numbers. The linguistic scale used to assess the main and sub-criteria in this study is shown in table 1.

Table 1. Linguistic expressions and corresponding triangular fuzzy numbers

\begin{tabular}{cc}
\hline Equally important & $(1,1,1)$ \\
Moderately more important & $(1,3,5)$ \\
Strongly more important & $(3,5,7)$ \\
Very strongly more important & $(5,7,9)$ \\
Demonstratively more important & $(7,9,9)$ \\
\hline
\end{tabular}

If there are more than one expert in the evaluation of the criteria, the aggregation process is carried out. There are many aggregation methods such as weighted average and geometric average method. The geometric mean method is used in this study. Aggregated pairwise matrix is given in the following equation;

$\tilde{C}=\left[\begin{array}{ccccc}1 & \tilde{c}_{12} & \tilde{c}_{13} & \ldots & \tilde{c}_{1 n} \\ \tilde{c}_{21} & 1 & \tilde{c}_{23} & \ldots & \tilde{c}_{2 n} \\ \cdot & \cdot & \cdot & \ldots & \cdot \\ \cdot & \cdot & \cdot & \ldots & \cdot \\ \tilde{c}_{n 1} & \tilde{c}_{n 2} & \tilde{c}_{n 3} & \ldots & 1\end{array}\right]$

where $\tilde{C}$ is the aggregated pairwise comparison matrix. After the aggregated pairwise comparison matrix is obtained, the calculation of the criteria weights is performed. Fuzzy weight matrix is determined by Buckley's method as below;

$\tilde{r}_{i}=\left(\tilde{c}_{i 1} \otimes \tilde{c}_{i 2} \otimes \ldots \otimes \tilde{c}_{i n}\right)^{1 / n}(3)$

$\widetilde{w}_{i}=\tilde{r}_{i} \otimes\left(\tilde{r}_{i}+\tilde{r}_{i}+\cdots+\tilde{r}_{i}\right)^{-1}(4)$

where $\tilde{r}_{i}$ is the geometric mean of the fuzzy comparison value of criterion $i$ to each criterion, $\widetilde{w}_{i}$ is the fuzzy weight of the $i^{\text {th }}$ criterion. At last stage, defuzzification and normalization operations are applied. In this study, centroid method is used in order to convert the fuzzy weight into crisp value. Centroid method is defined as below,

$w_{i}^{c}=\frac{w_{l}+w_{m}+w_{u}}{3}$

where $w_{i}^{c}$ is the crisp value of the $i^{\text {th }}$ criteria. $w_{l}, w_{m}, w_{u}$ that represent triangular fuzzy numbers indicates the lower bound the middle value and the upper bound, respectively. These values should be normalized to be more understandable and comparable. The normalization process is performed as follows, 


$$
\left(w_{i}^{N}\right)^{c}=\frac{w_{i}^{c}}{\sum_{i=1}^{n} w_{i}^{c}}
$$

\section{Application}

In this study, preferences of mushroom consumption were asked to the four experts. The two experts were selected from academicians who consume mushrooms at least once a week and who know the production of mushrooms. The remaining two experts were selected from the business man who trades mushrooms and specializes in consumer preferences All main and sub-criteria used in the study are given Figure 1.

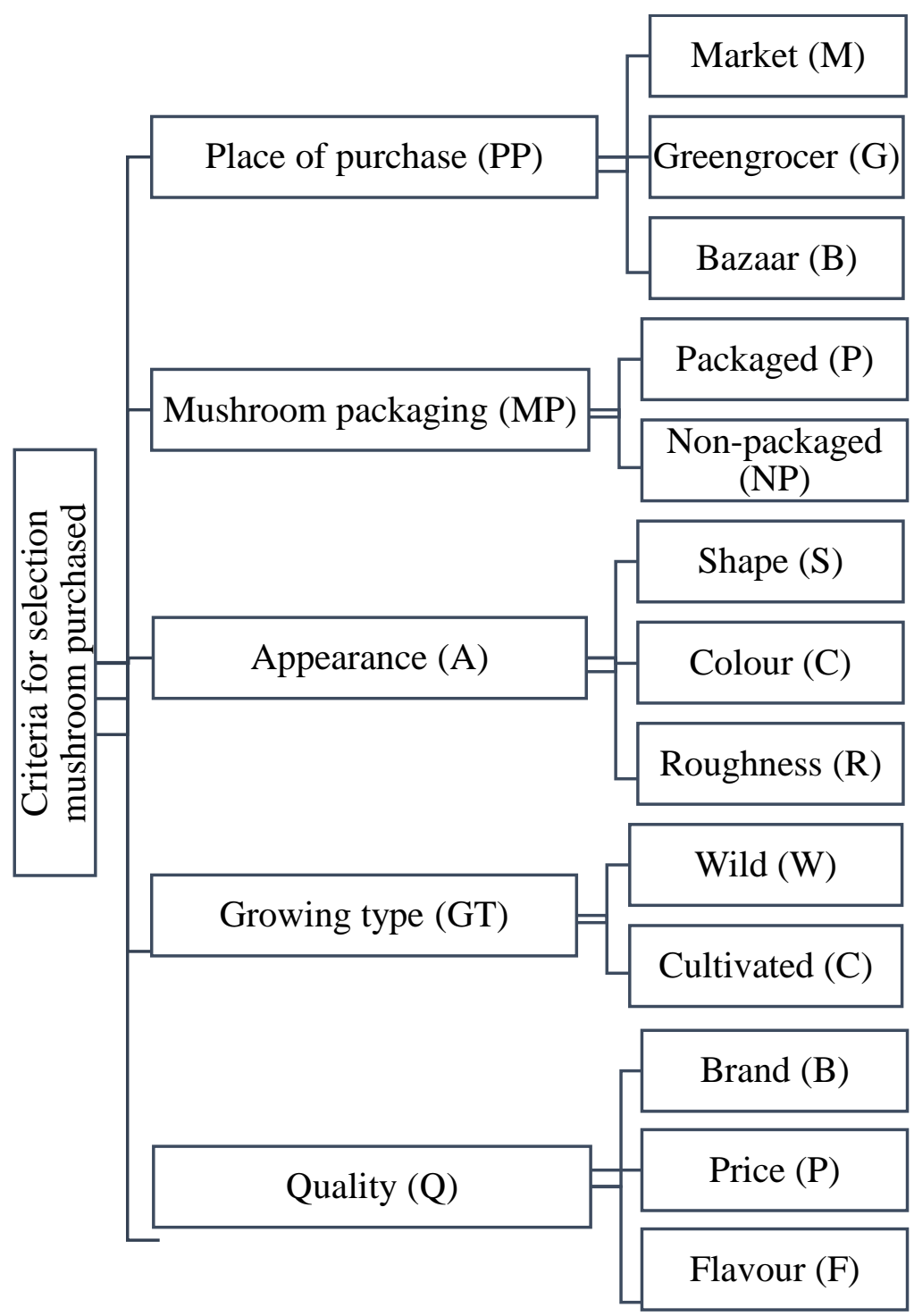

Figure 1. All main and sub-criteria used in the study

The linguistic answers given by experts have turned into fuzzy numbers. Linguistic terms used to evaluate the criteria and sub-criteria are given in Table 1.

The geometric mean method is used in this study to aggregate the preferences of four experts. Aggregated pairwise comparisons for the main criteria, place of purchase sub-criteria, mushroom packaging sub-criteria, appearance sub-criteria, growing type sub-criteria and quality sub-criteria are given in Table 2-7, respectively. 
Table 2. Aggregated pairwise comparisons for the main criteria

\begin{tabular}{lccccc}
\hline & Place of Purchase (PP) & Mushroom Packaging (MP) & Appearance (A) & Growing type (GT) & Quality (Q) \\
\hline PP & $(1.000,1.000,1.000)$ & $(0.377,0.447,0.577)$ & $(0.354,0.386,0.467)$ & $(0.128,0.155,0.252)$ & $(0.118,0.137,0.192)$ \\
MP & $(1.732,2.236,2.645)$ & $(1.000 .1 .000 .1 .000)$ & $(0.253,0.333,0.377)$ & $(0.111,0.134,0.183)$ & $(0.192,0.204,0.252)$ \\
A & $(2.140,2.590,2.817)$ & $(2.645,3.000,3.948)$ & $(1.000 .1 .000 .1 .000)$ & $(0.313,0.354,0.437)$ & $(0.810,1.000,1.233)$ \\
GT & $(3.956,6.422,7.770)$ & $(5.438,7.453,9.000)$ & $(2.284,3.000,3.474)$ & $(1.000 .1 .000 .1 .000)$ & $(0.863,0.939,1.064)$ \\
Q & $(5.206,7.296,8.451)$ & $(3.956,4.879,5.196)$ & $(0.810,1.064,1.341)$ & $(0.863,1.000,1.158)$ & $(1.000 .1 .000 .1 .000)$ \\
\hline
\end{tabular}

Table 3. Aggregated pairwise comparisons for the 'place of purchase' sub-criteria

\begin{tabular}{cccc}
\hline & Market $(\mathrm{M})$ & Bazaar $(\mathrm{B})$ & Greengrocer $(\mathrm{G})$ \\
\hline $\mathrm{M}$ & $(1.000,1.000,1.000)$ & $(1.967,4.212,6.299)$ & $(1.495,2.140,2.590)$ \\
$\mathrm{B}$ & $(0.158,0.237,0.508)$ & $(1.000,1.000,1.000)$ & $(0.332,0.508,0.939)$ \\
$\mathrm{G}$ & $(0.386,0.467,0.668)$ & $(1.064,1.967,3.006)$ & $(1.000,1.000,1.000)$ \\
\hline
\end{tabular}

Table 4. Aggregated pairwise comparisons for the 'mushroom packaging' sub-criteria

\begin{tabular}{ccc}
\hline & Packaged (P) & Non-packaged (NP) \\
\hline $\mathrm{P}$ & $(1.000,1.000,1.000)$ & $(3.482,4.486,4.879)$ \\
$\mathrm{NP}$ & $(0.204,0.222,0.287)$ & $(1.000,1.000,1.000)$ \\
\hline
\end{tabular}

Table 5. Aggregated pairwise comparisons for the 'appearance' sub-criteria

\begin{tabular}{cccc}
\hline & Shape $(\mathrm{S})$ & Color $(\mathrm{C})$ & Roughness $(\mathrm{R})$ \\
\hline $\mathrm{S}$ & $(1.000,1.000,1.000)$ & $(0.863,1.158,1.524)$ & $(2.140,3.408,4.212)$ \\
$\mathrm{C}$ & $(0.655,0.863,1.158)$ & $(1.000,1.000,1.000)$ & $(2.432,2.817,3.000)$ \\
$\mathrm{R}$ & $(0.237,0.293,0.467)$ & $(0.333,0.354,0.411)$ & $(1.000,1.000,1.000)$ \\
\hline
\end{tabular}

Table 6. Aggregated pairwise comparisons for the 'growing type' sub-criteria

\begin{tabular}{ccc}
\hline & Cultivated (C) & Wild (W) \\
\hline $\mathrm{C}$ & $(1.000,1.000,1.000)$ & $(1.527,1.844,2.006)$ \\
$\mathrm{W}$ & $(0.498,0.542,0.654)$ & $(1.000,1.000,1.000)$ \\
\hline
\end{tabular}

Table 7. Aggregated pairwise comparisons for the 'quality' sub-criteria

\begin{tabular}{cccc}
\hline & Brand (B) & Price $(\mathrm{P})$ & Flavor $(\mathrm{F})$ \\
\hline $\mathrm{B}$ & $(1.000,1.000,1.000)$ & $(0.939,1.233,1.524)$ & $(0.192,0.204,0.252)$ \\
$\mathrm{P}$ & $(0.655,0.810,1.064)$ & $(1.000,1.000,1.000)$ & $(0.111,0.125,0.169)$ \\
$\mathrm{F}$ & $(3.956,4.879,5.196)$ & $(4.786,6.852,8.451)$ & $(1.000,1.000,1.000)$ \\
\hline
\end{tabular}

The weights of criteria were calculated after the aggregation of pairwise comparisons according to Buckley's method. Then, the weights were defuzzificatied and normalized. The degrees of importance of all main and sub-criteria are given in Table 8 .

Table 8. The degrees of importance of all main and sub-criteria 


\begin{tabular}{llll}
\hline Main and sub-criteria & Fuzzy weights & Normalized crisp weights & $\begin{array}{l}\text { Relative crisp } \\
\text { weights }\end{array}$ \\
\hline Place of Purchase (PP) & $\mathbf{( 0 . 0 3 7 , 0 . 0 4 8 , 0 . 0 7 5 )}$ & $\mathbf{0 . 0 5 1}$ & \\
Market (M) & $(0.312,0.586,0.993)$ & 0.564 & 0.028 \\
Bazaar (B) & $(0.081,0.139,0.306)$ & 0.157 & 0.008 \\
Greengrocer (G) & $(0.162,0.274,0.494)$ & 0.277 & 0.014 \\
Mushroom Packaging (MP) & $\mathbf{( 0 . 0 5 0 , 0 . 0 6 8 , 0 . 0 9 7 )}$ & $\mathbf{0 . 0 6 9}$ & \\
Packaged (P) & $(0.452,0.684,1.012)$ & 0.688 & 0.047 \\
Non-packaged (NP) & $(0.254,0.315,0.402)$ & 0.311 & 0.021 \\
Appearance (A) & $(\mathbf{0 . 1 3 8 , 0 . 1 8 1 , 0 . 2 5 6 )}$ & $\mathbf{0 . 1 8 5}$ & \\
Shape (S) & $(0.310,0.465,0.657)$ & 0.460 & 0.085 \\
Colour (C) & $(0.295,0.396,0.536)$ & 0.394 & 0.072 \\
Roughness (R) & $(0.108,0.138,0.204)$ & 0.144 & 0.026 \\
Growing type (GT) & $(\mathbf{0 . 2 7 2 , 0 . 3 9 5 , 0 . 5 4 4 )}$ & $\mathbf{0 . 3 8 9}$ & \\
Cultivated (C) & $(0.379,0.545,0.776)$ & 0.552 & 0.214 \\
Wild (W) & $(0.376,0.454,0.545)$ & 0.447 & 0.173 \\
Quality (Q) & $(\mathbf{0 . 2 1 9 , 0 . 3 0 6 , 0 . 4 1 7 )}$ & $\mathbf{0 . 3 0 3}$ & 0.045 \\
Brand (B) & $(0.117,0.146,0.199)$ & 0.150 & 0.034 \\
Price (P) & $(0.086,0.108,0.154)$ & 0.113 & 0.222 \\
Flavour (F) & $(0.552,0.745,0.966)$ & 0.735 & \\
\hline
\end{tabular}

\section{Results}

Criteria weights which calculated according to Buckley's method are compared each other. Figure 2 shows the degrees of importance for main criteria among themselves. The results can be ranked according to their importance as follows: growing type > quality > appearance > mushroom packaging $>$ place of purchase. Consumers first consider the growing type of mushroom when they buy mushrooms. After the growing type of mushroom, the quality of the mushroom is the most important criterion for consumers.

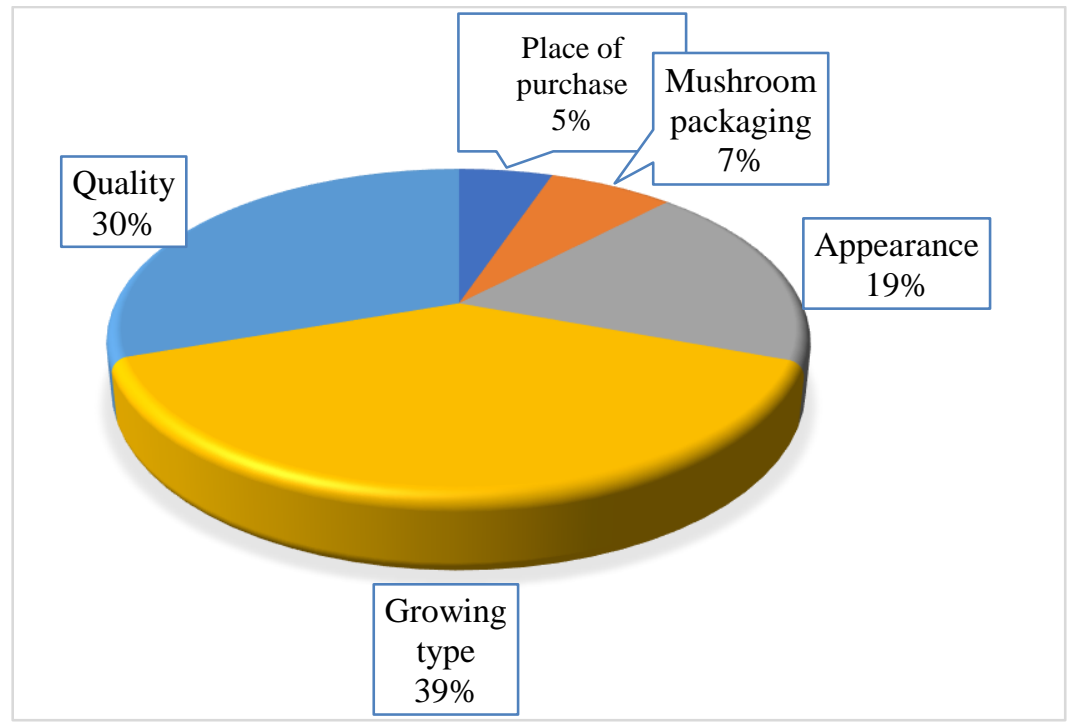

Figure 2. The degrees of importance for main criteria 
The degrees of importance for the 'place of purchase' sub-criteria are shown in Figure 3. According to the results, consumers prefer to buy mushrooms primarily (56\%) from the market. This result may be due to the higher confidence in the markets.

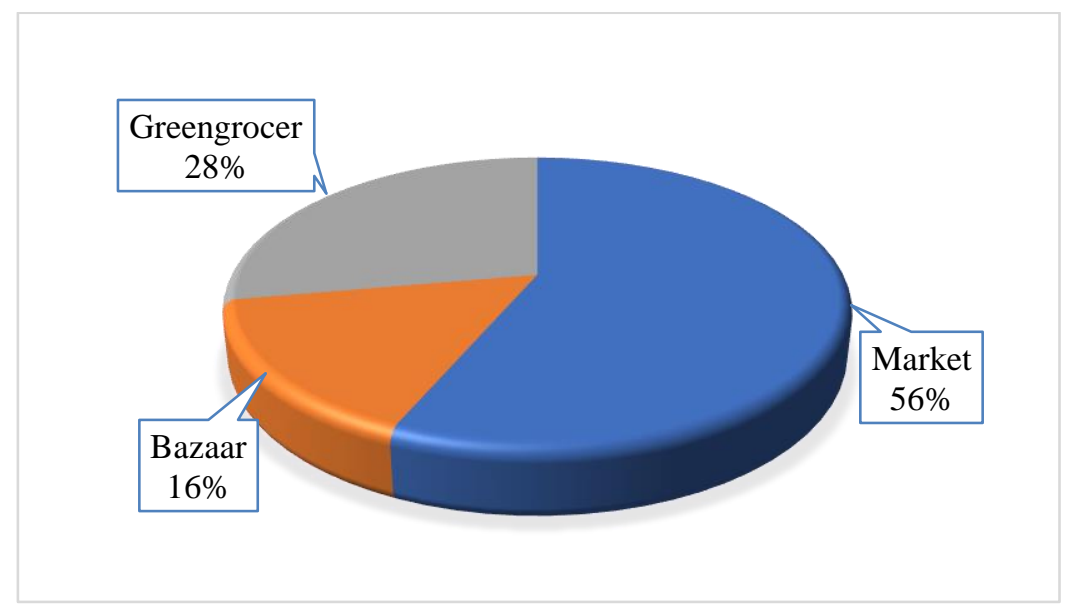

Figure 3. The degrees of importance for the 'place of purchase' sub-criteria

Figure 4 displays the sub-criteria of mushroom packaging. As can be seen, packaged mushroom is the more significant with $69 \%$ weight than non-packaged mushroom. it can be said that consumers find packaged products more reliable / healthier.

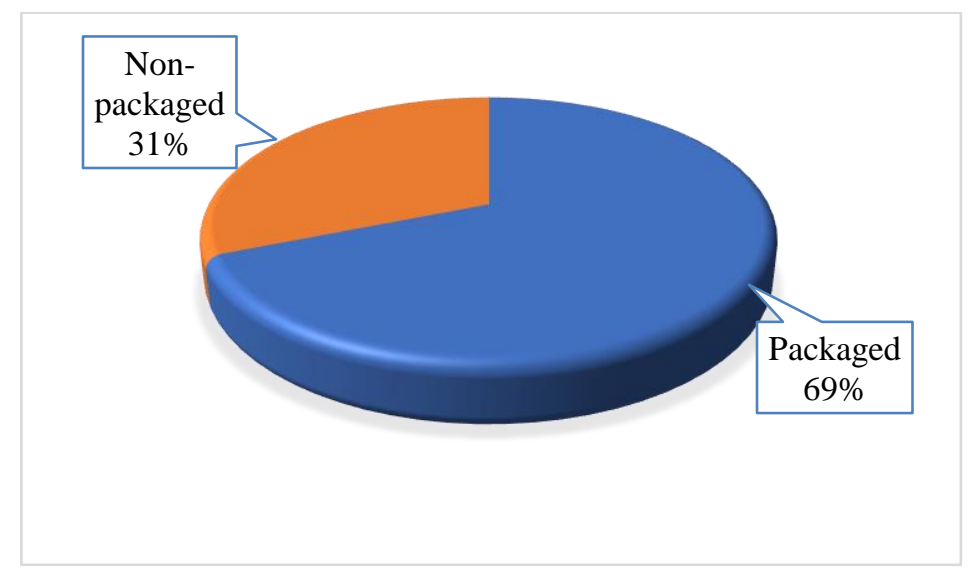

Figure 4. The degrees of importance for the 'mushroom packaging' sub-criteria

Figure 5. Displays the sub-criteria of appearance of mushroom. As can be seen at Figure 5, the most significant sub-criteria is shape of mushroom with \%46 weight. 


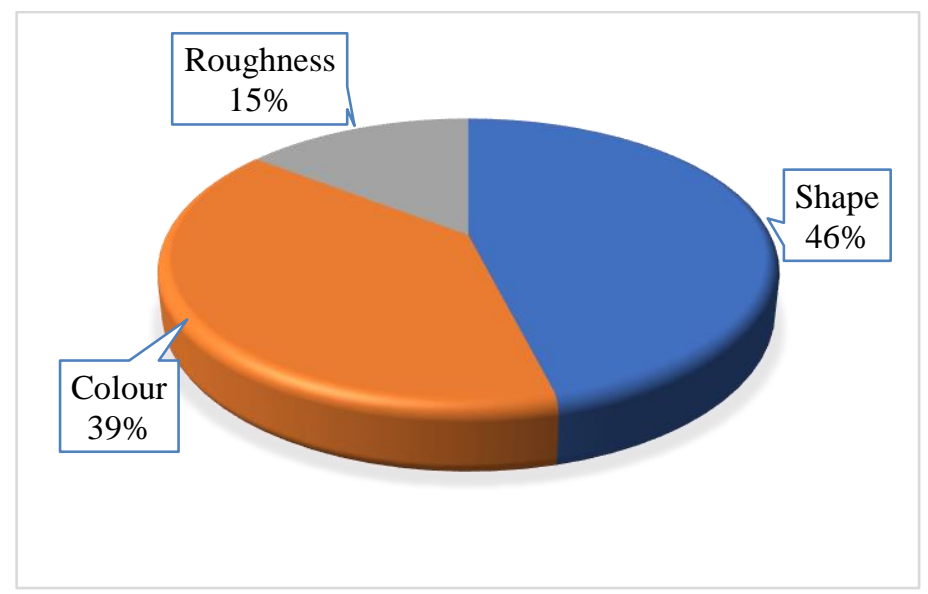

Figure 5. The degrees of importance for the 'appearance' sub-criteria

Figure 6, which examines the sub-criteria of growing type of mushroom, shows the cultivated mushrooms are important than wild mushrooms. Consumers may prefer cultivated mushrooms because of fear of poisoning of wild mushrooms.

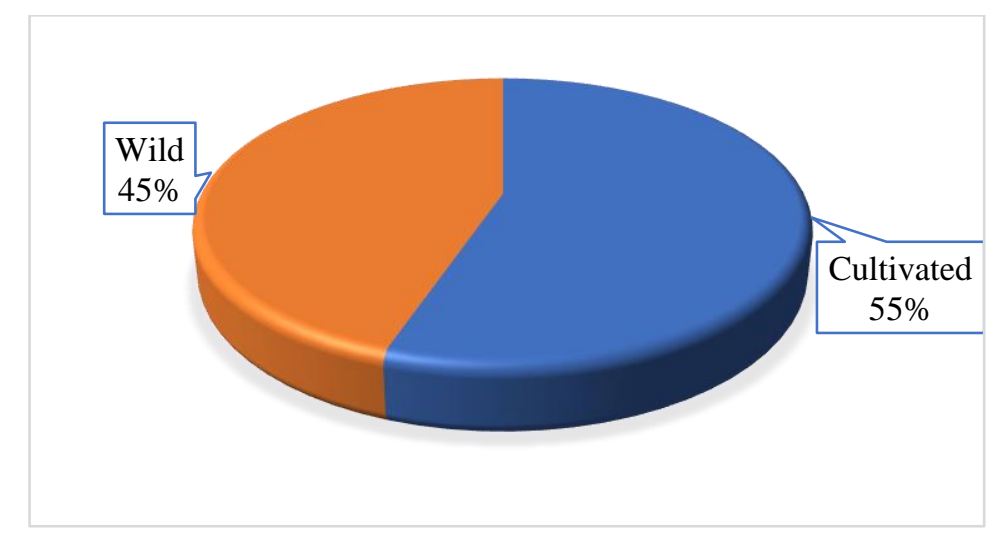

Figure 6. The degrees of importance for the 'growing type' sub-criteria

Figure 7 depicts the weights of the sub-criteria of mushroom quality. Among the all sub-criteria flavor of mushroom is the most significant criteria with $\% 74$ weight. According to the results, consumers pay less attention to brand and price of mushrooms $\% 15$ and $\% 11$ weight, respectively. 


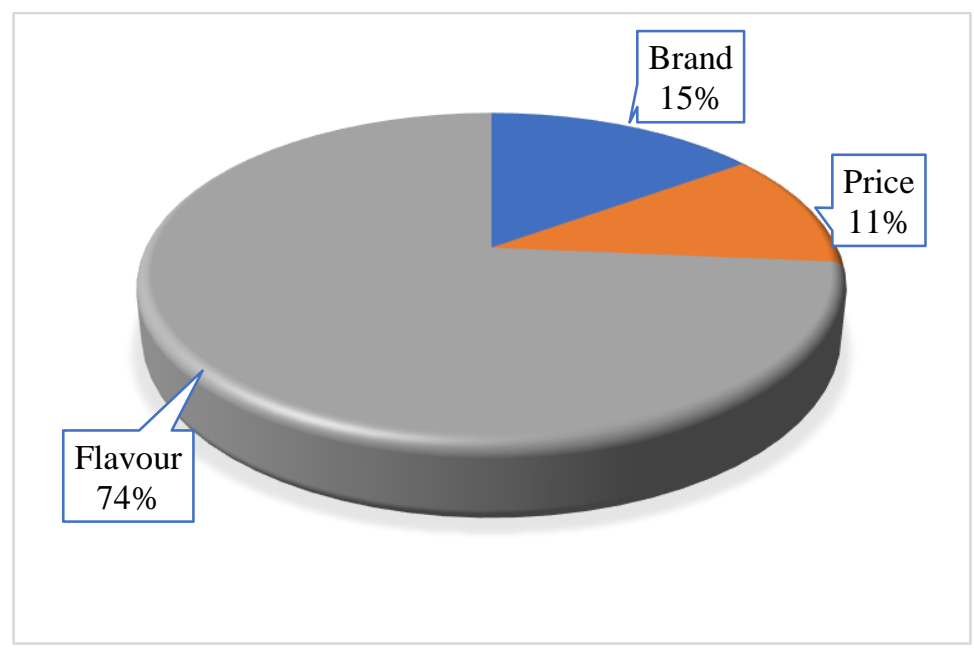

Figure 7. The degrees of importance for the 'quality' sub-criteria

\section{Conclusion}

In this study, mushroom consumption preferences were investigated using the fuzzy AHP. Surveys were answered by expert consumers. The important findings of the study can be listed as follows.

- Growing type of mushroom is the most significant criteria, among the all main criteria.

- The most important criteria is the market among the place of purchase sub-criteria.

- Packaged mushrooms are preferred ton on-packaged mushrooms.

- The weight of cultivated mushroom are higher than wild mushroom weight.

- When the mushroom quality sub-criteria are all evaluated together, flavour is the most important sub-criteria.

\section{References}

Baraza, L. D., Neser, W., Jackson, K. C., Fredrick, J. B., Dennis, O., Wairimu, K. R., Keya, A. O.,Heydenreich, M. (2016). Antimicrobial coumarins from the oyster culinary-medicinal mushroom, Pleurotus ostreatus (Agaricomycetes), from Kenya. International Journal of Medicinal Mushrooms 18(10): 905-913.

Buckley, J.J. (1985). Fuzzy hierarchical analysis. Fuzzy Sets and Systems 17(3): 233-247.

Danell, E.,Eaker, D. (1992). Amino acid and total protein content of the edible mushroom Cantharellus cibarius (Fries). Journal of the Science of Food and Agriculture60(3): 333-337.

Eren, E.,Pekşen, A. (2014). Türkiye'de kültür mantarı üretimi, sorunları ve çözüm yolları. 1. Ulusal Mikoloji Günleri (1-4 Eylül 2014) Özet Kitabı(s 29).

Karsak, E.E.,Tolga, E. (2001). Fuzzy multi-criteria decision-making procedure for evaluating advanced manufacturing system investments. International Journal of Production Economics, 69(1): 49-64.

Kavishree, S., Hemavathy, J., Lokesh, B., Shashirekha, M.,Rajarathnam, S. (2008). Fat and fatty acids of Indian edible mushrooms. Food Chemistry, 106(2): 597-602.

Kızılaslan, N.,Kızılaslan, H. (2008). Tüketicilerin satın aldıkları gıda maddeleri ile ilgili bilgi düzeyleri ve tutumları (Tokat ili örneği). Uludağ Üniversitesi Ziraat Fakültesi Dergisi 22(2): 67-74.

Manzi, P., Aguzzi, A.,Pizzoferrato, L. (2001). Nutritional value of mushrooms widely consumed in Italy. Food Chemistry 73(3): 321-325. 
Özkan B, A.F., Özçatalbaş O, Kutlar İ, (2000).Antalya ve Ankara illerinde mantar tüketicilerinin mantar satın alma davranışlarının analizi. Türkiye VI. Yemeklik Mantar Kongresi, İzmir.

Paksoy, M.,Aksüt, M. (2012). Mantar Tüketimi Ve Tüketim Alışkanlıklarının Belirlenmesi: Kahramanmaraş İli Örneği. Türkiye Yemeklik Mantar Kongresi, Pamukkale Üniversitesi, 173-183.

Patel, S.,Goyal, A. (2012). Recent developments in mushrooms as anti-cancer therapeutics: a review. 3 Biotech, 2(1): $1-15$.

Saaty, T.L. (1977). A scaling method for priorities in hierarchical structures. Journal of Mathematical Psychology 15(3): 234-281.

Sevindik, M., Akgul, H., Korkmaz, A.,Sen, İ. (2018). Antioxidant potantials of Helvella leucomelaena and Sarcosphaera coronaria. Journal of Bacteriology \& Mycology:Open Access 6(2): 00173.

TUIK. (2018). Bitkisel Üretim İstatistikleri, Başka yerde sınıflandırılmamış diğer sebzeler, 1988-2017. Retrieved from http://www.tuik.gov.tr/PreTablo.do?alt_id=1001. Last accessed date: 12.06 .2018

Yilmaz, A., Yildiz, S., Yildirim, İ.,Aydin, A. (2016). Trabzon'da Mantar Tüketimi ve Tüketim Alışkanlıklarının Belirlenmesi. Mantar Dergisi7(2): 135-142.

Yoon, K. P.,Hwang, C.-L. (1995). Multiple attribute decision making: an introduction (Vol. 104): Sage publications.

Zadeh, L. A. (1965). Fuzzy sets. Inform and Control8: 338-353.

Zikmund, W. G.,d'Amico, M. (1998). Effective marketing: Creating and keeping customers: South Western.

\section{Appendix}

Appendix 1. Main criteria survey

\begin{tabular}{|c|c|c|c|c|c|c|c|c|c|c|}
\hline & 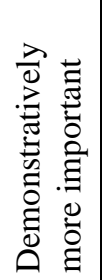 & 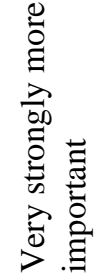 & 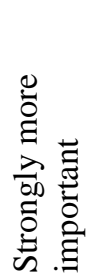 & 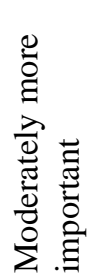 & 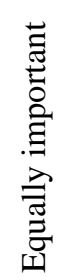 & 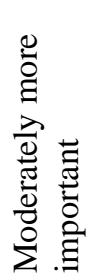 & 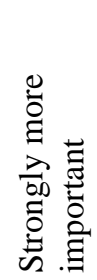 & 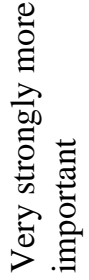 & 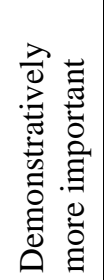 & \\
\hline Place of Purchase & & & & & & & & & & $\begin{array}{l}\text { Mushroom } \\
\text { Packaging }\end{array}$ \\
\hline Place of Purchase & & & & & & & & & & Appearance \\
\hline Place of Purchase & & & & & & & & & & Growing type \\
\hline Place of Purchase & & & & & & & & & & Quality \\
\hline Mushroom Packaging & & & & & & & & & & Appearance \\
\hline Mushroom Packaging & & & & & & & & & & Growing type \\
\hline Mushroom Packaging & & & & & & & & & & Quality \\
\hline Appearance & & & & & & & & & & Growing type \\
\hline Appearance & & & & & & & & & & Quality \\
\hline Growing type & & & & & & & & & & Quality \\
\hline
\end{tabular}

Submitted: 12.06 .2018

Accepted: 26.10.2018 